\title{
EFEKTIVITAS GEL EKSTRAK KASAR BROMELIN KULIT NANAS (Ananus comosus L. Merr) HASIL OPTIMASI FORMULA PADA TIKUS YANG DIBUAT LUKA MEMAR
}

\author{
Anang Setyo Wiyono, Dian Mustofani \\ Analis Farmasi dan Makanan, Institut IImu Kesehatan Bhakti Wiyata Kediri \\ Email : anang.wiyono@iik.ac.id
}

\begin{abstract}
Pineapple (Ananus comosus L. Merr) peel contains a protease enzyme, it was called bromelain. The purpose of this study was to develop a crude extract of bromelain of pineapple peel to be formulated into a gel and to determine the effects of crude extract of bromelain of pineapple peel gel on injury healing of rats skin contusion. Fresh pineapple peel carried out in order to get a crude extract of bromelain using the Herdyastuti's method (2006) then formulated into a gel preparations with variations in the concentration of gelling agent and humectant. The evaluation of the quality of gel preparations were carried out, which included organoleptic test, homogeneity test, dispersion test, $\mathrm{pH}$ test, and viscosity test. The results of the evaluation of the quality of gel preparations were optimized using Simplex Lattice Design (SLD) to applied into 3 (three) dosage variations of the crude extract of bromelain of pineapple peel, namely $150 \mathrm{mg} / \mathrm{KgBB}, 300 \mathrm{mg} / \mathrm{KgBB}$, and $450 \mathrm{mg} / \mathrm{KgBB}$. The results showed that there was an effect of the concentration of carbopol 940 and glycerin on the organoleptic test, dispersion test, $\mathrm{pH}$ test and viscosity test, and there was no effect of the concentration of carbopol 940 and glycerin on homogeneity tests. The 3 (three) dosage variations of the optimum gel formula have healing activity on rats skin contusion.
\end{abstract}

Key Words: Bromelain, contusion, gel, injury healing, pineapple peel.

\section{PENDAHULUAN}

Kulit nanas mengandung enzim bromelin. ${ }^{1}$ Enzim bromelin merupakan enzim yang dapat menghidrolisis ikatan peptida pada kandungan protein menjadi asam amino. Pada bidang kesehatan enzim bromelin dapat untuk mengurangi memar. ${ }^{19}$ Memar disebabkan rusaknya kapiler darah yang menyebabkan darah menyerap ke daerah sekitarnya dan pada akhirnya menimbulkan memar dan sakit Ekstrak kasar kulit buah nanas memiliki efek antimemar karena mempunyai aktivitas fibrinolisa dan antikoagulan. ${ }^{20}$

Ekstrak kasar bromelin kulit nanas dalam penelitian ini akan dibuat sediaan gel yang difungsikan sebagai bahan aktif gel antimemar. Sediaan gel aplikasinya ditujukan untuk kulit atau pada permukaan kulit untuk aksi lokal. Sediaan gel merupakan sediaan yang memiliki daya sebar yang baik, memberikan efek dingin pada kulit, tidak menyumbat pori-pori kulit, mudah dicuci dengan air dan memungkinkan pemakaian pada bagian tubuh yang berambut dan pelepasan obatnya baik. ${ }^{21}$

Carbopol merupakan basis gel hidrofilik. ${ }^{5}$ Keuntungan gel hidrofilik adalah daya sebarnya pada kulit baik, efek dingin yang ditimbulkan akibat lambatnya penguapan air pada kulit, tidak menyumbat pori-pori kulit, mudah dicuci dengan air dan memungkinkan pemakaian pada bagian tubuh yang berambut dan pelepasan obatnya baik. ${ }^{21}$ Carbopol 940 sendiri memiliki viskositas dengan range antara 40.000-60.000 mPas, sedangkan carbopol 934 memiliki viskositas 30.50039.400 mPas. $^{5}$ Viskositas adalah suatu pernyataan tahanan dari suatu cairan untuk mengalir, makin tinggi viskositasnya akan makin besar tahannya. ${ }^{11}$ Carbopol 940 
Efektivitas gel ekstrak kasar bromelin kulit nanas (Ananus comosus L. Merr) hasil optimasi formula pada tikus yang dibuat luka memar.

merupakan gelling agent yang dapat membentuk gel pada konsentrasi rendah. $^{5}$ Gliserin sendiri merupakan humektan yang dapat mempertahankan air pada sediaan. ${ }^{5}$ Untuk mendapatkan kombinasi optimum Carbopol 940 dan gliserin maka dilakukan optimasi secara Simplex Lattice Design berdasarkan parameter uji mutu fisik gel. Simplex Lattice Design merupakan suatu metode yang dapat digunakan untuk menentukan proporsi relatif bahan-bahan yang digunakan dalam suatu formulasi sehingga diharapkan akan dapat dihasilkan formulasi yang paling baik. ${ }^{22}$

\section{METODE PENELITIAN}

Penelitian dilakukan di Laboratorium Solida dan Semi Solida Fakultas Farmasi Institut IImu Kesehatan Bhakti Wiyata Kediri. Waktu Penelitian dilaksanakan pada bulan Mei - Juli 2019. Bahan yang digunakan adalah kulit buah nanas, buffer fosfat $\mathrm{pH} 7$, natrium metabisulfit $0,2 \%, \mathrm{NaOH}$, larutan CuSO4 encer, HNO3 pekat, carbopol 940, triethanolamin, gliserin, metil paraben, aquadest, alkohol 70\%. Peralatan yang digunakan adalah blender, pisau, kain kasa, sentrifus, spatel, ayakan, timbangan analitik, cawan, oven, pipet tetes, gelas ukur, mortir, stamper, beaker glass, tabung reaksi wadah gel, viskometer rion VT-04F, lempeng gelas, keping kaca, $\mathrm{pH}$ meter, timbangan hewan, jangka sorong, pipa paralon, beban 250 gram.

\section{Prosedur Kerja}

Kulit nanas yang telah dibersihkan, dipotong kecil - kecil, kemudian diblender dengan buffer fosfat $\mathrm{pH}$ 7. Preparat halus disaring untuk mendapatkan sari yang selanjutnya disimpan dalam lemari es selama 24 jam. Endapan yang muncul di sentrifus dengan kecepatan 3.500 rpm selama 15 menit sehingga diperoleh tiga lapisan. Lapisan pertama yaitu lapisan atas berupa cairan, lapisan kedua yaitu berupa koloid yang mengandung enzim bromelain dan lapisan ketiga berupa pati. Selanjutnya koloid tersebut ditambahkan natrium metabisulfit $0.2 \%$ sebanyak tiga kali berat koloid yang diperoleh, kemudian koloid ini dikeringkan pada suhu \pm $55^{\circ} \mathrm{C}$ selama lebih kurang 7 jam hingga di peroleh ekstrak kering. Kemudian koloid digerus dan diayak dengan ayakan mesh $48 .^{2}$ Uji Biuret. Metode biuret dilakukan dengan cara sampel dibuat alkalis dengan $\mathrm{NaOH}$ kemudian ditambahkan larutan $\mathrm{CuSO} 4$ encer. Uji ini memberikan reaksi positif yang ditandai dengan timbulnya warna merah violet atau biru violet ${ }^{2}$

Uji Xantoprotein. Larutan $\mathrm{HNO} 3$ pekat ditambahkan dengan hati-hati ke dalam sampel. Setelah tercampur sempurna akan terjadi endapan putih yang dapat berubah menjadi kuning apabila dipanaskan. ${ }^{2}$

Uji Alkohol. Sampel ditambahkan pelarut alkohol. Uji ini akan bereaksi positif apabila terbentuk gumpalan. ${ }^{2}$

Formulasi Gel. Formulasi sediaan gel ekstrak kasar bromelin kulit nanas secara Simplex Lattice Design dapat dilihat pada tabel 1.

\section{Pembuatan Gel}

Pembuatan gel dilakukan dengan cara carbopol dimasukkan ke dalam mortir yang berisi air, ditunggu sampai mengembang dan digerus sampai homogen. Selanjutnya ditambahkan triethanolamin sedikit demi sedikit ke dalam mortir yang berisi carbopol, digerus sampai homogen dan terbentuk massa gel. Gliserin dan ekstrak kasar ditambahkan ke dalam mortir yang berisi massa gel, digerus sampai homogen. Metil paraben dilarutkan dengan air panas dan 
Efektivitas gel ekstrak kasar bromelin kulit nanas (Ananus comosus L. Merr) hasil optimasi formula pada tikus yang dibuat luka memar.

dimasukkan ke dalam mortir yang berisi

Kemudian dimasukkan sediaan ke dalam massa gel, lalu diaduk sampai homogen. wadah. $^{21}$

Tabel 1. Formulasi gel

\begin{tabular}{cccc}
\hline Nama Bahan & \multicolumn{3}{c}{ Formulasi (gram) } \\
\cline { 2 - 4 } & F1 & F2 & F3 \\
\hline Ekstrak kasar & 0,3 & 0,3 & 0,3 \\
Carbopol & 0 & 1 & 2 \\
TEA & 0,2 & 0,2 & 0,2 \\
Gliserin & 2 & 1 & 0 \\
Metil paraben & 0,02 & 0,02 & 0,02 \\
Air add & 10 & 10 & 10 \\
\hline
\end{tabular}

Uji Organoleptis. Uji organoleptis gel dilakukan dengan cara mengamati tekstur, warna, dan bau secara visual. ${ }^{7}$

Uji Homogenitas. Gel dioleskan pada dua keping kaca. Sediaan harus menunjukkkan homogen dan tidak terlihat adanya butiran kasar. $^{23}$

Uji pH. Uji pH gel dilakukan menggunakan pH meter. Alat terlebih dahulu dikalibrasi dengan larutan dapar standart pH 4 dan 7 sebelum digunakan untuk uji $\mathrm{pH}$ gel. ${ }^{23}$

Uji Daya Sebar. Uji daya sebar gel dilakukan dengan cara menimbang gel ekstrak kasar bromelin kulit buah nanas sebanyak 500 mg, gel ekstrak kasar bromelin kulit buah nanas diletakkan diatas pusat antara 2 lempeng gelas. Lempeng gelas bagian atas sebelumnya ditimbang kemudian letakkan diatas gel selama 1 menit, Lempeng gelas bagian atas diberi beban dan biarkan selama 1 menit. $^{21}$

Uji Viskositas. Uji viskositas gel dilakukan dengan cara menyiapkan sampel dalam viskometer rion VT-04F hingga spindle terendam. Spindle dan kecepatan yang akan digunakan kemudian diatur. Viskometer rion VT-04F dijalankan, kemudian viskositas dari gel akan terbaca. ${ }^{21}$

Uji Efektivitas Terhadap Hewan Coba Pembuatan Luka Memar Pada Hewan Coba
Sebelum dibuat luka memar, seluruh tikus dilakukan pembiusan terlebih dahulu menggunakan eter. Rambut di area yang akan dilukai dicukur terlebih dahulu dan kulit didesinfeksi dengan alkohol 70\%. Pembuatan luka memar pada paha tikus menggunakan beban sebesar 250 gram yang dijatuhkan secara vertikal melalui pipa paralon dengan ketinggian $70 \mathrm{~cm} .{ }^{14}$ Menurut Robin et al., $(2015)^{23}$ penyembuhan luka memar diperoleh melalui pengukuran diameter luka memar setelah dijatuhi beban. Pengukuran dilakukan dengan menggunakan jangka sorong dan diamati pada jam ke-1, jam ke-3, jam ke-6, jam ke-9, jam ke-12 dan jam ke-15 jam.

\section{Pembagian Kelompok Sampel}

Penelitian ini menggunakan 5 kelompok perlakuan, masing-masing kelompok terdiri dari 5 ekor tikus putih jantan (Rattus norvegicus). Kelompok perlakuan dibagi sebagai berikut :

1. Kelompok I (kontrol positif) : Luka memar dioleskan dengan Thrombophob gel.

2. Kelompok II (normal) : Luka memar dibiarkan tanpa perlakuan.

3. Kelompok III : Luka memar dioleskan gel ekstrak kasar kulit buah nanas hasil formulasi optimum dosis $150 \mathrm{mg} / \mathrm{KgBB}$.

4. Kelompok IV : Luka memar dioleskan gel ekstrak kasar kulit buah nanas hasil formulasi optimum dosis $300 \mathrm{mg} / \mathrm{KgBB}$. 
Efektivitas gel ekstrak kasar bromelin kulit nanas (Ananus comosus L. Merr) hasil optimasi formula pada tikus yang dibuat luka memar.

5. Kelompok V : Luka memar dioleskan gel formulasi optimum dosis $450 \mathrm{mg} / \mathrm{KgBB}$. ekstrak kasar kulit buah nanas hasil

\section{HASIL DAN PEMBAHASAN}

Tabel 2. Hasil ekstrak kasar bromelin kulit nanas

\begin{tabular}{cccc}
\hline $\begin{array}{c}\text { Berat Kulit Buah } \\
\text { Nanas (gram) }\end{array}$ & $\begin{array}{c}\text { Larutan Buffer Fosfat pH } \\
\mathbf{7}(\mathbf{m L})\end{array}$ & $\begin{array}{c}\text { Berat Ekstrak Kasar Bromelin } \\
\text { Kulit Nanas (gram) }\end{array}$ & Rendemen (\%) \\
\hline 2000 & 1000 & 3.814 & 0.19 \\
\hline
\end{tabular}

Tabel 3. Hasil identifikasi kualitatif ekstrak kasar bromelin kulit nanas

\begin{tabular}{|c|c|c|c|c|}
\hline Identifikasi & Pengujian & $\begin{array}{l}\text { Hasil (+) } \\
\text { Literatur }\end{array}$ & $\begin{array}{c}\text { Hasil } \\
\text { Pengujian }\end{array}$ & Ket \\
\hline Metode Biuret & $\begin{array}{c}\text { Sampel }+\mathrm{NaOH} \text { (dibuat } \\
\text { alkalis) + larutan } \mathrm{CuSO}_{4} \\
\text { encer }\end{array}$ & $\begin{array}{c}\text { Warna merah } \\
\text { violet atau biru } \\
\text { violet }\end{array}$ & Warna biru violet & $(+)$ \\
\hline Reaksi Xantoprotein & $\begin{array}{c}\text { Larutan } \mathrm{HNO}_{3} \text { pekat }+ \\
\text { sampel }\end{array}$ & $\begin{array}{l}\text { Endapan Putih } \\
\rightarrow \uparrow \text { kuning }\end{array}$ & $\begin{array}{l}\text { Endapan Putih } \\
\rightarrow \uparrow \text { kuning }\end{array}$ & $(+)$ \\
\hline Pelarut Alkohol & Sampel + pelarut alkohol & $\begin{array}{l}\text { Terbentuk } \\
\text { gumpalan }\end{array}$ & Terbentuk gumpalan & $(+)$ \\
\hline
\end{tabular}

Hasil pemeriksaan kualitatif ekstrak kasar bromelin kulit nanas menunjukkan hasil positif pada metode biuret karena terbentuk warna biru violet. Uji ini memberikan reaksi positif yang ditandai dengan timbulnya warna merah violet atau biru violet. Prinsip dari metode biuret sendiri adalah bahwa ikatan peptida dapat membentuk senyawa kompleks berwarna ungu dengan penambahan garam kupri dalam suasana basa. Warna violet adalah hasil dari reaksi positif untuk 2 atau lebih ikatan peptide. ${ }^{3}$ Pada reaksi xantoprotein juga menunjukkan hasil positif dengan terbentuknya endapan putih dan berubah menjadi kuning bila dipanaskan. Uji Xantoprotein digunakan untuk mendeteksi adanya cincin benzen aktif pada suatu protein. Jika protein yang mengandung cincin benzena (tirosin, triptofan, dan fenilalanin) ditambahkan asam nitrat pekat, maka akan terbentuk endapan putih yang dapat berubah menjadi kuning sewaktu dipanaskan. ${ }^{4}$ Pemeriksaan ekstrak kasar bromelin kulit nanas dengan pelarut alkohol juga menunjukkan hasil positif dengan terbentuknya gumpalan. Hal ini terjadi karena bromelin dapat mengendap jika ditambahkan dengan pelarut organik, seperti alkohol sebab bromelin praktis tidak larut dalam aseton, alkohol, kloroform, dan eter. ${ }^{2}$

Gel Formula I, II, dan III berwarna putih kekuningan karena ekstrak yang ditambahkan berwarna putih kekuningan. Bau yang dihasilkan oleh gel yaitu bau khas kulit nanas yang merupakan bahan aktif yang digunakan dalam formulasi. Pemeriksaan berdasarkan tampilan fisik pada tekstur gel pada Formula I terbentuk gel cair, sedangkan gel pada Formula II terbentuk gel kental, dan gel pada Formula III terbentuk gel sangat kental. Hal ini disebabkan karena pada formulasi I tidak menggunakan carbopol, sedangkan carbopol sendiri berfungsi sebagai gelling agent. ${ }^{5}$ Tujuan dibuat 3 formulasi ini adalah untuk mendapatkan komposisi optimum melalui perhitungan Simplex Lattice Design. Metode ini mempunyai keuntungan praktis dan cepat karena bukan merupakan penentuan formulasi dengan coba - coba (trial and error). 
Efektivitas gel ekstrak kasar bromelin kulit nanas (Ananus comosus L. Merr) hasil optimasi formula pada tikus yang dibuat luka memar.

Tabel 4. Hasil pemeriksaan organoleptis ekstrak kasar bromelin kulit nanas

\begin{tabular}{cc}
\hline Pemeriksaan & Hasil \\
\hline Bentuk & Serbuk \\
Warna & Putih Kekuningan \\
Bau & Khas \\
\hline
\end{tabular}

Tabel 5. Hasil uji organoleptis gel ekstrak kasar bromelin kulit nanas

\begin{tabular}{ccllc}
\hline Formulasi & Replikasi & Warna & Bau & Bentuk \\
\hline Formulasi & 1 & Putih Kekuningan & Khas & Cair \\
I & 2 & Putih Kekuningan & Khas & Cair \\
& 3 & Putih Kekuningan & Khas & Cair \\
Formulasi & 1 & Putih Kekuningan & Khas & Kental \\
II & 2 & Putih Kekuningan & Khas & Kental \\
& 3 & Putih Kekuningan & Khas & Kental \\
Formulasi & 1 & Putih Kekuningan & Khas & Sangat Kental \\
III & 2 & Putih Kekuningan & Khas & Sangat Kental \\
& 3 & Putih Kekuningan & Khas & Sangat Kental
\end{tabular}

Keterangan :

Formulasi I : Formulasi gel ekstrak kasar bromelin kulit nanas dengan konsentrasi tanpa carbopol 940 dan gliserin 2 gram Formulasi II :Formulasi gel ekstrak kasar bromelin kulit nanas dengan konsentrasi carbopol 9401 gram dan gliserin 1 gram Formulasi III : Formulasi gel ekstrak kasar bromelin kulit nanas dengan konsentrasi carbopol 9402 gram dan tanpa gliserin

Pembuatan gel ekstrak kasar bromelin ini menggunakan Carbopol 940 sebagai gelling agent yang memiliki konsentrasi sebesar $0.5 \%$ - $2 \%$. Carbopol umumnya digunakan karena tidak beracun dan non iritan. ${ }^{5}$ Gliserin berfungsi sebagai humektan. ${ }^{5}$ Humektan membantu menjaga kelembaban kulit dengan mekanisme yaitu menjaga kandungan air pada lapisan stratum korneum serta mengikat air dari lingkungan ke kulit. Selain sebagai humektan, gliserin juga dipakai sebagai pelarut metil paraben (nipagin). ${ }^{5}$ Penambahan triethanolamine (TEA) sebagai alkalizing agent yaitu menetralkan suasana asam carbopol agar sediaan mencapai $\mathrm{pH}$ yang sesuai dengan karakteristik $\mathrm{pH}$ kulit yaitu
4.5 - 6.5, selain itu juga dapat digunakan sebagai emulsifying agent (pembentuk massa gel). ${ }^{5}$ Penambahan TEA mengakibatkan adanya pergeseran keseimbangan ion membentuk garam yang larut. Adanya tolak menolak ionik antara gugus karboksilat menghasilkan polimer yang kaku, peningkatan viskositas dan gel yang jernih. Metil paraben merupakan bahan pengawet yang baik karena kelarutannya yakni 1: 400 dalam air. Metil paraben juga berfungsi sebagai antimikroba karena formulasi gel memiliki kandungan air yang tinggi dalam sediaan yang dapat menyebabkan terjadinya kontaminasi mikroba, dan aquadest digunakan sebagai pelarut dalam formulasi gel. ${ }^{5}$

Tabel 6. Hasil uji daya sebar gel ekstrak kasar bromelin kulit nanas

\begin{tabular}{ccccc}
\hline Formulasi & Replikasi & $\begin{array}{c}\text { Beban } \\
\text { (gram) }\end{array}$ & $\begin{array}{c}\text { Diameter } \\
\text { (cm) }\end{array}$ & $\begin{array}{c}\text { Rata-Rata } \\
\text { (cm) } \pm \text { SD }\end{array}$ \\
\hline \multirow{2}{*}{ Formulasi } & 1 & 150 & 7,9 & \\
I & 2 & 150 & 8.0 & $8.1 \pm 0,264$ \\
& 3 & 150 & 8.4 & \\
Formulasi & 1 & 150 & 6.6 & $6.5 \pm 0,057$ \\
II & 2 & 150 & 6,6 & \\
\hline \multirow{2}{*}{ Formulasi } & 3 & 150 & 6,5 & $5.1 \pm 0,1$ \\
III & 1 & 150 & 5,0 & \\
\hline
\end{tabular}


Efektivitas gel ekstrak kasar bromelin kulit nanas (Ananus comosus L. Merr) hasil optimasi formula pada tikus yang dibuat luka memar.

Daya sebar gel dimaksudkan untuk mengetahui kemampuan gel menyebar saat dioleskan pada kulit. Hasil pengujian daya sebar gel ekstrak kasar kulit buah nanas (Ananas comosus (L.) Merr) memiliki nilai rata - rata penyebaran pada formulasi I, II, dan III berturut - turut sebesar $8.1 \mathrm{~cm}, 6.5 \mathrm{~cm}$, dan $5.1 \mathrm{~cm}$. Daya sebar yang dihasilkan dari sediaan formulasi I dan II memenuhi kriteria daya sebar yang baik untuk sediaan gel yaitu antara $5-7 \mathrm{~cm} .{ }^{6,7}$ Namun, formulasi I tidak memenuhi kriteria daya sebar yang baik dimana daya sebar yang dihasilkan yaitu 8.1 $\mathrm{cm}$, hal ini disebabkan karena konsistensi dari sediaan yang terlalu cair sehingga daya sebarnya menjadi lebih besar. Uji daya sebar bertujuan untuk mengetahui kemampuan penyebaran gel mudah atau tidaknya diaplikasikan pada kulit. $^{7}$ Profil kurva daya sebar menunjukkan bahwa semakin kecil konsentrasi carbopol 940 dan semakin besar konsentrasi gliserin menghasilkan nilai daya sebar yang tinggi. Sebaliknya, semakin besar konsentrasi carbopol 940 dan semakin kecil konsentrasi gliserin menghasilkan nilai daya sebar yang rendah. Penurunan daya sebar terjadi melalui meningkatnya ukuran unit molekul karena telah mengabsorbsi pelarut sehingga cairan tersebut tertahan dan meningkatkan tahanan untuk mengalir dan menyebar. ${ }^{8}$ Kriteria ini dipilih karena semakin tinggi daya sebar suatu sediaan maka luas permukaannya semakin besar, mengakibatkan kecepatan difusi suatu obatpun semakin meningkat. $^{7}$

Tabel 7. Hasil uji homogenitas gel ekstrak kasar bromelin kulit nanas

\begin{tabular}{ccc}
\hline Formulasi & Replikasi & Keterangan \\
\hline \multirow{2}{*}{ Formulasi I } & 1 & Homogen \\
& 2 & Homogen \\
\multirow{2}{*}{ Formulasi II } & 3 & Homogen \\
& 1 & Homogen \\
& 2 & Homogen \\
\hline \multirow{2}{*}{ Formulasi III } & 3 & Homogen \\
& 1 & Homogen \\
\hline
\end{tabular}

Tabel 8. Hasil uji ph gel ekstrak kasar bromelin kulit nanas

\begin{tabular}{cccc}
\hline Formulasi & Replikasi & pH & Rata-Rata \pm SD \\
\hline \multirow{2}{*}{ Formulasi I } & 1 & 6.1 & 6 \\
& 2 & 6.0 & \\
& 3 & 6.0 & \\
\multirow{2}{*}{ Formulasi II } & 1 & 6.1 & $6.13 \pm 0.152$ \\
& 2 & 6.0 & \\
& 3 & 6.3 & $5.03 \pm 0.057$ \\
\multirow{2}{*}{ Formulasi III } & 1 & 5.0 & \\
& 2 & 5.1 &
\end{tabular}

Hasil homogenitas gel ekstrak kasar kulit buah nanas menunjukkan bahwa tidak ada butiran kasar atau partikel pada sediaan yang terlihat pada obyek glass dan tercampur rata. Pengujian homogenitas merupakan pengujian terhadap ketercampuran bahan bahan dalam sediaan gel yang menunjukkan susunan yang homogen. Uji homogenitas bertujuan untuk melihat ketercampuran bahan - bahan dalam sediaan gel yang menunjukkan 
Efektivitas gel ekstrak kasar bromelin kulit nanas (Ananus comosus L. Merr) hasil optimasi formula pada tikus yang dibuat luka memar.

susunan yang homogen. Pengujian yang dilakukan dengan cara sampel gel dioleskan pada sekeping kaca atau bahan transparan yang cocok, sediaan harus menunjukkan susunan yang homogen dan terlihat adanya butiran kasar. ${ }^{9}$

Hasil pengujian $\mathrm{pH}$ menunjukkan bahwa nilai $\mathrm{pH}$ yang dihasilkan gel ekstrak kasar kulit buah nanas dalam rentang $\mathrm{pH}$ kulit yaitu antara 4.5 - 6.5. Nilai rata - rata $\mathrm{pH}$ formulasi I, II, III secara berturut - turut adalah 6.03, 6.13 dan 5.03. Semua formulasi memiliki nilai $\mathrm{pH}$ yang berada pada rentang $\mathrm{pH}$ fisiologis kulit yaitu $4.5-6.5$, sehingga aman untuk pemakaian ${ }^{(10)}$. Profil kurva $\mathrm{pH}$ menunjukkan bahwa semakin kecil konsentrasi carbopol 940 dan semakin tinggi konsentrasi gliserin maka $\mathrm{pH}$ yang dihasilkan semakin mendekati normal. Hal ini juga terjadi saat konsentrasi carbopol 940 dan gliserin sama yaitu sebesar 1 gram. Tetapi semakin tinggi konsentrasi carbopol 940 dan semakin kecil konsentrasi gliserin maka $\mathrm{pH}$ yang dihasilkan semakin mendekati asam. Menurunnya nilai $\mathrm{pH}$ atau semakin asam disebabkan karena banyaknya konsentrasi carbopol 940 yang ditambahkan, semakin tinggi konsentrasi carbopol maka semakin asam $\mathrm{pH}$ sediaan gel ekstrak kasar kulit buah nanas kulit buah nanas. Carbopol 940 didispersikan ke dalam air membentuk larutan asam kemudian dinetralkan dengan basa kuat seperti trietanolamin yang akan mengurangi keasaman dari formulasi tersebut. ${ }^{5}$ Penelitian ini menggunakan kriteria $\mathrm{pH}$ kulit yaitu 4.5 6.5. Kriteria ini dipilih karena $\mathrm{pH}$ yang terlalu asam dapat mengiritasi kulit dan $\mathrm{pH}$ yang terlalu basa dapat membuat kulit bersisik. ${ }^{10}$

Tabel 9. Hasil uji viskositas gel ekstrak kasar bromelin kulit nanas

\begin{tabular}{cccc}
\hline Formulasi & Replikasi & Viskositas (dPa's) & Rata-Rata (dPa's) \pm SD \\
\hline \multirow{2}{*}{ Formulasi I } & 1 & 0.5 & $0.5 \pm 0$ \\
& 2 & 0.5 & \\
\multirow{2}{*}{ Formulasi II } & 3 & 0.5 & $170 \pm 0$ \\
& 1 & 170 & \\
\hline \multirow{2}{*}{ Formulasi III } & 2 & 170 & $300 \pm 0$ \\
& 3 & 170 & \\
& 1 & 300 & \\
\hline
\end{tabular}

Viskositas merupakan tahanan untuk mengalir, dimana semakin besar viskositasnya maka sediaan tersebut semakin kental, demikian juga sebaliknya. Hasil pengujian viskositas, diperoleh hasil yang bervariasi pada tiap formulasi. Formulasi I memiliki nilai rata - rata viskositas sebesar $0.5 \mathrm{dPa}$. Formulasi II memiliki nilai rata - rata viskositas 170 dPa's. Formulasi III memiliki nilai rata rata viskositas 300 dPa's. Viskositas merupakan tahanan dari suatu cairan yang mengalir, nilai viskositas berbanding lurus dengan tahanannya. ${ }^{11}$ Uji viskositas bertujuan untuk mengetahui konsistensi suatu sediaan yang berpengaruh pada penggunaan secara topikal. Profil kurva viskositas yang dihasilkan dari persamaan menunjukkan bahwa semakin tinggi konsentrasi carbopol 940 dapat meningkatkan viskositas gel, meningkatnya viskositas ini karena carbopol dapat mengembang ketika terdispersi dalam air membentuk suatu koloid. Namun, viskositas sediaan tidak boleh terlalu tinggi maupun terlalu rendah, karena viskositas yang terlalu 
Efektivitas gel ekstrak kasar bromelin kulit nanas (Ananus comosus L. Merr) hasil optimasi formula pada tikus yang dibuat luka memar.

tinggi akan membuat gel semakin kental yang mengakibatkan pada semakin sulit obat terlepas dari sediaan gel, sedangkan jika viskositas terlalu rendah maka akan menurunkan lama waktu gel tinggal di kulit saat digunakan. ${ }^{12}$ Gel formulasi II dan III menghasilkan viskositas yang baik dan tingkat kejernihan yang bagus. Sifat fisik tersebut dijadikan dasar untuk menentukan kriteria viskositas yang optimal dalam penelitian ini.

Tabel 10. Hasil uji organoleptis gel formula optimum ekstrak kasar bromelin kulit nanas

\begin{tabular}{ccccc}
\hline Formulasi & Replikasi & Warna & Bau & Bentuk \\
\hline Formulasi & 1 & Putih Kekuningan & Khas & Kental \\
Optimum & 2 & Putih Kekuningan & Khas & Kental \\
Metode SLD & 3 & Putih Kekuningan & Khas & Kental \\
\hline
\end{tabular}

Keterangan :

Formulasi Optimum Metode Simplex Lattice Design :

Formulasi gel ekstrak kasar kulit buah nanas dengan konsentrasi carbopol 9401 gram dan gliserin 1 gram.

Gel dengan konsentrasi carbopol 940 1 gram dan gliserin 1 gram berwarna putih kekuningan karena ekstrak yang ditambahkan berwarna putih kekuningan. Bau yang dihasilkan oleh gel yaitu bau khas kulit nanas yang merupakan bahan aktif yang digunakan dalam formulasi. Pemeriksaan berdasarkan tampilan fisik pada tekstur gel dengan konsentrasi carbopol 9401 gram dan gliserin 1 gram terbentuk gel kental. Optimasi sediaan gel ekstrak kasar kulit buah nanas dalam penelitian ini didasarkan pada pengujian terhadap uji $\mathrm{pH}$, uji daya sebar, dan uji viskositas gel berdasarkan program design expert 7.1.5. Selanjutnya dengan metode Simplex Lattice Design melalui pendekatan secara numerik, ditemukan satu formulasi optimal yaitu formulasi dengan komposisi carbopol sebesar 1 gram dan gliserin sebesar
1 gram. Dari program ditemukan nilai desirability sebesar 0.805 . Nilai desirability dipengaruhi oleh jumlah respon dan target yang ingin dicapai untuk memperoleh formulasi optimum ${ }^{(13)}$. Formulasi ini diprediksi mempunyai $\mathrm{pH} 6.1$, daya sebar $6.5 \mathrm{~cm}$, dan viskositas $170 \mathrm{dPa}$. Hasil yang diperoleh melalui penelitian pada formulasi tersebut menghasilkan pH $6.1 \mathrm{~cm}$, daya sebar 6.5 , dan viskositas $163 \mathrm{dPa}$.

Pengujian homogenitas merupakan pengujian terhadap ketercampuran bahan bahan dalam sediaan gel yang menunjukkan susunan yang homogen. Hasil homogenitas gel ekstrak kasar kulit buah nanas menunjukkan bahwa tidak ada butiran kasar atau partikel pada sediaan yang terlihat pada obyek glass dan tercampur rata.

Tabel 11. hasil uji homogenitas gel formula optimum ekstrak kasar bromelin kulit nanas

\begin{tabular}{ccc}
\hline Formulasi & Replikasi & Keterangan \\
\hline Formulasi & 1 & Homogen \\
Optimum Metode SLD & 2 & Homogen \\
& 3 & Homogen \\
\hline
\end{tabular}

Tabel 12. Hasil uji daya sebar gel formulasi optimum ekstrak kasar bromelin kulit nanas

\begin{tabular}{ccccc}
\hline Formulasi & Replikasi & $\begin{array}{c}\text { Beban } \\
(\mathbf{g r a m})\end{array}$ & $\begin{array}{c}\text { Diameter } \\
(\mathbf{c m})\end{array}$ & $\begin{array}{c}\text { Rata-Rata } \\
(\mathbf{c m}) \pm \text { SD }\end{array}$ \\
\hline Formulasi & 1 & 150 & 6.5 & \\
Optimum Metode SLD & 2 & 150 & 6.7 & $6.5 \pm 0,152$ \\
\hline
\end{tabular}


Efektivitas gel ekstrak kasar bromelin kulit nanas (Ananus comosus L. Merr) hasil optimasi formula pada tikus yang dibuat luka memar.

Hasil pengujian daya sebar gel formulasi optimum ekstrak kasar kulit buah nanas (Ananas comosus (L.) Merr) memiliki nilai rata -rata penyebaran sebesar 6,5 cm. Daya sebar gel dimaksudkan untuk mengetahui kemampuan gel menyebar saat dioleskan pada kulit. Daya sebar yang dihasilkan dari sediaan memenuhi kriteria daya sebar yang baik untuk sediaan gel yaitu antara $5-7 \mathrm{~cm} .{ }^{6}$ Dari program juga ditemukan nilai optimasi daya sebar dengan prediksi $6,5 \mathrm{~cm}$. Hasil pengujian $\mathrm{pH}$ menunjukkan bahwa nilai $\mathrm{pH}$ yang dihasilkan gel formulasi optimum ekstrak kasar kulit buah nanas dalam rentang $\mathrm{pH}$ kulit yaitu 4.5-6.5. Nilai rata - rata $\mathrm{pH}$ formulasi optimum sebesar 6.13 sehingga hasil prediksi metode Simplex Lattice Design sesuai dengan nilai $\mathrm{pH}$ hasil penelitian.

Tabel 13. Hasil uji ph gel formulasi optimum ekstrak kasar bromelin kulit nanas

\begin{tabular}{cccc}
\hline Formulasi & Replikasi & pH & Rata-Rata \pm SD \\
\hline Formulasi Optimum & 1 & 6.30 & \\
Metode SLD & 2 & 6.00 & $6.13 \pm 0.152$ \\
\hline
\end{tabular}

Tabel 14. Hasil uji viskositas gel formulasi optimum ekstrak kasar bromelin kulit nanas

\begin{tabular}{cccc}
\hline Formulasi & Replikasi & $\begin{array}{c}\text { Viskositas } \\
\text { (dPa's) }\end{array}$ & $\begin{array}{c}\text { Rata-Rata } \\
\text { (dPa's) } \pm \text { SD }\end{array}$ \\
\hline Formulasi & 1 & 150 & $160 \pm 10$ \\
Optimum Metode SLD & 2 & 170 & 160 \\
\hline
\end{tabular}

Hasil pengujian viskositas pada gel formulasi optimum memiliki nilai rata - rata sebesar $160 \mathrm{dPa}$ 's. Sedangkan, pada program ditemukan nilai optimasi viskositas dengan prediksi $170 \mathrm{dPa}$ 's. Pengujian hasil uji $\mathrm{pH}$, viskositas dan daya sebar formulasi optimum dengan hasil penelitian dianalisa menggunakan uji $\mathrm{T}$ ( $T$-test). Sebelumnya dilakukan uji Normalitas untuk mengetahui penyebaran data normal atau tidak, setelah dianalisa diperoleh nilai signifikan pada masing - masing uji yaitu uji pH sebesar 0.637 , uji viskositas sebesar 1.000, dan uji daya sebar sebesar 0.637 yang berarti penyebaran data normal (sig $>0,05)$. Selanjutnya dilakukan uji $\mathrm{T}$, pengujian ini dimaksudkan untuk mengetahui signifikansi dari pengaruh hasil uji mutu fisik prediksi Simplex Lattice Design terhadap hasil penelitian yang dilakukan. Hasil pengujian uji $\mathrm{pH}$, uji viskositas, dan uji daya sebar menunjukkan tidak ada beda signifikan karena nilai sig > 0,05 .
Hewan coba yang digunakan dalam penelitian ini adalah tikus putih (Rattus norvegicus) jantan galur wistar dengan berat $\pm 200-300$ g. Penelitian ini menggunakan beban dengan berat $250 \mathrm{~g}$ yang dijatuhkan bebas melalui pipa paralon dengan ketinggian $70 \mathrm{~cm}$ untuk memberikan efek memar pada hewan coba. Beban dijatuhkan melalui ketinggian $70 \mathrm{~cm}$ karena menghasilkan satu tingkat cedera yaitu ringan sampai sedang. Sedangakan beban yang dijatuhkan diatas ketinggan $70 \mathrm{~cm}$, hewan coba akan mengalami cedera dengan tingkat keparahan yang tinggi dan cenderung mengalami fraktur tibia serta fibula. ${ }^{14}$

Sediaan gel merupakan sediaan topikal yang digunakan untuk mendapatkan efek lokal di lokasi aplikasi berdasarkan penetrasi obat ke dalam lapisan yang mendasari kulit atau mukosa membran. Keuntungan utama sistem pelepasan topikal adalah untuk menghindari first pass effect, menghindari resiko ketidaknyamanan terapi 
Efektivitas gel ekstrak kasar bromelin kulit nanas (Ananus comosus L. Merr) hasil optimasi formula pada tikus yang dibuat luka memar.

intravena, perubahan $\mathrm{pH}$, dan waktu pengosongan lambung. ${ }^{15}$ Obat dapat mempenetrasi kulit setelah pemakaian topikal melalui dinding folikel rambut, kelenjar keringat, kelenjar lemak, antara sel-sel dari selaput tanduk (stratum korneum), dan lapisan epidermis. Absorpsi obat pada umumnya disebabkan oleh penetrasi langsung obat melalui stratum korneum. Komponen lemak pada stratum korneum merupakan faktor utama yang mempengaruhi rendahnya penetrasi obat. Ketika obat dapat melalui stratum korneum, obat akan diteruskan melalui epidermis dan masuk ke lapisan dermis. Apabila obat mencapai pembuluh kulit maka obat tersebut siap diabsorpsi ke dalam sirkulasi umum. Stratum korneum bersifat semipermiabel, molekul obat mempenetrasi lapisan ini dengan difusi pasif. Konsentrasi obat yang masuk ke lapisan kulit tergantung pada dosis obat, kelarutannya dalam air, dan koefisien partisi minyak dan airnya. Bahan bahan yang dapat larut dalam minyak dan air merupakan bahan yang baik untuk berdifusi melalui lapisan kulit. $^{16}$

Ada dua jalur utama penetrasi obat, yaitu penetrasi transepidermal dapat secara interseluler dan intraseluler serta penetrasi melalui pori dapat secara transfolikular dan transgrandular. Partisi obat yang bersifat hidrofilik masuk ke dalam jalur rute intraseluler, sedangkan obat dengan sifat lipofilik akan melewati stratum korneum melewati rute interselluler. Penetrasi interseluler merupakan jalur yang dominan, obat akan menembus stratum korneum melalui ruang antar sel pada lapisan lipid yang mengelilingi sel korneosit. Difusi dapat berlangsung pada matriks lipid protein dari stratum korneum. Setelah berhasil menembus stratum korneum obat akan menembus lapisan epidermis sehat dibawahnya, hingga akhirnya berdifusi ke pembuluh kapiler. Penetrasi secara intraseluler terjadi melalui difusi obat menembus dinding stratum korneum sel korneosit yang mati dan juga melintasi matriks lipid protein stratum korneum, kemudian melewatinya menuju sel yang berada di lapisan bawah sampai pada kapiler dibawah stratum basal epidermis dan berdifusi ke kapiler. ${ }^{17}$

Kontrol positif yang digunakan dalam penelitian ini adalah Thrombophob gel. Thrombophob gel digunakan juga sebagai pembanding, karena Thrombophop gel adalah obat antimemar yang biasa digunakan serta memiliki aktivitas yang hampir sama dengan bromelin. Thrombophob gel merupakan suatu bentuk terapi baru heparin sodium bagi kulit. Heparin bisa mencegah pembekuan pada darah serta membantu proses fibrinolisa, butir - butir bekuan darah atau mikrotrombi yang ada di sekitar kulit bisa diserap lebih cepat. $^{18}$

Kontrol normal tidak memiliki efek antimemar pada hewan coba, yang artinya tidak terdapat penyembuhan luka memar. Sebab dari pengamatan hasil diameter luka memar pada jam ke-3 mengalami penambahan diameter luka memar dan puncaknya terjadi pada jam ke-6. Kemudian berangsur -angsur mengalami penurunan diameter memar pada jam ke-9, jam ke- 12 dan ke-15. Hal ini juga dikarenakan secara normal tubuh akan merespon proses regenerasi dari kulit karena sel epitel, endotel dan jaringan ikat bisa diproduksi. Terbentuknya epitel menunjukkan bahwa respon terhadap kerusakan jaringan atau organ serta usaha pengembalian kondisi 
Efektivitas gel ekstrak kasar bromelin kulit nanas (Ananus comosus L. Merr) hasil optimasi formula pada tikus yang dibuat luka memar.

homeostatis sehingga dicapai kestabilan

fisiologis jaringan atau organ yang pada kulit terjadi penyusunan kembali jaringan kulit yang mengurangi diameter luka memar. ${ }^{18}$

\section{KESIMPULAN}

Hasil penelitian menunjukkan ada pengaruh konsentrasi carbopol 940 dan gliserin terhadap uji organoleptis, uji daya sebar, uji pH dan uji viskositas dan tidak ada pengaruh konsentrasi carbopol 940 dan gliserin terhadap uji homogenitas. 3 (tiga) variasi dosis ekstrak kasar bromelin kulit nanas yaitu dosis $150 \mathrm{mg} / \mathrm{KgBB}, 300$ $\mathrm{mg} / \mathrm{KgBB}$, dan $450 \mathrm{mb} / \mathrm{KgBB}$ pada sediaan gel hasil formulasi optimum memiliki aktivitas antimemar.

\section{DAFTAR PUSTAKA}

1. Murniati E. Sang Nanas Bersisik Manis di Lidah. Surabaya: SIC, 2006.

2. Herdyastuti N. Isolasi dan Karakterisasi Ekstrak Kasar Enzim Bromelin dari Batang Nanas (Ananas comosus L. Merr). Jurnal Berk. Penel. Hayati. 2006;12:75-77.

3. Goretti M. Perbandingan Analisa Kadar Protein Terlarut Dengan Berbagai Metode Speektroskopi UV-Visible. Jurnal IImiah Sains Dan Teknologi. 2014;7(2):64-70.

4. Putri AAB. Analisis Kadar Albumin Ikan Sidat (Anguilla marmorata dan Anguilla bicolor) dan Uji Aktivitas Penyembuhan Luka Terbuka Pada Kelinci (Oryctolagus cuniculus). Galenika Journal of Pharmacy. 2016;2:(2):90-95.

5. Rowe RC, Sheskey PJ, and Owen SC. Handbook of Pharmaceutical Excipients. Sixth edition. Washington dan London: American Pharmaceutical Association and the Pharmaceutical Society of Great Britain, 2009.

6. Sayuti NA. Fomulasi dan Uji Stabilitas Fisik Sediaan Gel Ekstrak Daun Ketepeng Cina (Cassia alata L.) (Formulation and Physical Stability of Cassia alata L. Leaf Extract Gel). Surakarta: Artikel Riset Jurnal Kefarmasian Indonesia, Jurusan Jamu Poltekkes Kemenkes, 2015.
7. Ulviani, Fina, Yusriadi, dan Khildah. Pengaruh Gel Ekstrak Daun Sirih Merah (Piper crocatum Ruiz \& Pav) Terhadap Penyembuhan Luka Bakar Pada Kelinci (Oryctolagus cuniculus). Galenika Journal of Pharmacy. 2016;3(1):49-56.

8. Sukmawati. Pengaruh Variasi Konsentrasi Pva, Hpmc, Dan Gliserin Terhadap Sifat Fisika Masker Wajah Gel Peel Off Ekstrak Etanol 96\% Kulit Buah Manggis (Garcinia mangostana L.) (Skripsi). Bali: Jurusan Farmasi-Fakultas Matematika dan IImu Pengetahuan Alam-Universitas Udayana, 2011.

9. Depkes RI. Farmakope Indonesia Edisi Keempat. Jakarta: Depkes RI, 1995.

10. Olivia H. Pengaruh Basis Salep Terhadap Formulasi Sediaan Salep Ekstrak Daun Kemangi (Ocinum sanctum L) Pada Kulit Punggung Kelinci Yang Dibuat Infeksi Staphylococcus aureus. Manado: FMIPAUNSRAT, 2013.

11. Sinko PJ. Martin Farmasi Fisika dan IImu Farmasetika. Edisi 5. Jakarta: EGC., 2011.

12. Madan J, and Singh R. Formulation and Evaluation of Aloevera Topical Gels. Int.J.Ph.Sci. 2010;2(2):551-555.

13. Engelina. Optimasi Krim Sarang Burung Walet Putih (Aerodramus fuciphagus) Tipe $\mathrm{M} / \mathrm{A}$ dengan Variasi Emulgator sebagai Pencerah Kulit Menggunakan Simplex Lattice Design. Pontianak: Universitas Tanjungpura, 2013.

14. McBrier NM, Neuberger T, Okita N, Webb A, Sharkey N. Reliability and Validity of a Novel Muscle Contusion Device. Journal of Athletic Training. 2009/;44(3):275-278.

15. Ahmad J, Mir SR, Kohli K, and Amin S. Effect Of Oil and Co-Surfactant on the Formation of Solutol HS 15 Based Colloidal Drug Carrier by Box-Behnken Statistical Design. Colloids and Surfaces A: Physicochemical and Engineering Aspects. 2014;453: 68-77.

16. Ansel HC. Pengantar Bentuk Sediaan Farmasi. Edisi IV. Jakarta: Universitas Indonesia Press., 1989.

17. Yanhendri and Yenny SW. Berbagai Bentuk Sediaan Topikal dalam Dermatologi. C.D.K., 2012;39(6):423-30. 
Efektivitas gel ekstrak kasar bromelin kulit nanas (Ananus comosus L. Merr) hasil optimasi formula pada tikus yang dibuat luka memar.

18. Asparini RR. Peran Heparin Dalam Angiogenesis, Epitelialisasi Dan Penyembuhan Luka Bakar. Saintika Medika.2011;7(1):26-32.

19. Lakshminarasimaiah N, RajaRajeshwari BV, Barnali G. Extraction Of Bromelain From Pineapple Waste. International Journal of Scientific \& Engineering Research. 2014;5(6):763-766.

20. Pavan R, Sapha J, Shraddha, Kumar A. Properties and Therapeutic Application of Bromelain: A Review. Biotechnology Research International. 2012:1-6.
21. Voight. Buku Ajar Teknologi Farmasi. Diterjemahkan oleh Soendani Noeroto S., Yogjakarta: UGM Press.,1995.

22. Kurniawan DW, and Sulaiman TNS. Teknologi Sediaan Farmasi. Yogjakarta: Graha IImu., 2009.

23. Robin S, Carol C, Tauzin H, Harbon S, Marlene C, Cadars B, Jourdan E, Trompezinski $S$, Humbert $P$. Use of a Model of a Blood-Induced Bruise for the Evaluation of Formulations on Bruising. Journal of Cosmetics, Dermatological Sciences and Applications. 2015;5:7-14. 